\title{
NUTRITIONAL EVALUATION OF SUBSTITUTING MORINGA OLEIFERA LEAVES MEAL (MOLM) AS A SOURCE OF PROTEIN INSTEAD OF SOYBEAN MEAL IN DIETS OF GROWING RABBITS IN NORTH SINAI
}

\author{
E. O. A. Bakr \\ Department of Animal and Poultry Production, Faculty of Environmental Agricultural Sciences, Arish \\ University, North Sinai, Egypt.
}

(Received 15/5/2019, accepted 4/7/2019)

\section{SUMMARY}

$\mathrm{T}$ he objective of this study was to evaluate the utilization of Moringa oleifera leaves meal (MOLM) as a source of protein in feeding growing rabbits. Thirty six weaned New Zealand white rabbits of both sexes aged $6 \mathrm{wk}$ and weighted $858 \mathrm{~g}$ were randomly divided into three groups (12 each). Rabbits were fed ad-libitum diets containing $0,7.5$ and $15 \%$ MOLM for groups T0, T7.5 and T15, respectively as a substitute for soybean meal. Fresh water was supplied ad-libitum during the experimental period ( $8 \mathrm{wk}$ ). At the end of experimental period, digestibility trials were carried out to determine the digestibility of feed nutrients and the feeding values of experimental diets. Three rabbits from each group were slaughtered to evaluate carcass traits and some blood parameters. Results revealed that substituting MOLM instead of soybean meal in rabbit's diets did not significantly affect live body weight (LBW), daily weight gain (DWG) and total feed intake (TFI). Meanwhile, feed conversion ratio was significantly affected by inclusion of MOLM in the diet, however, control group (T0) recorded the best value (4.28) followed by $15 \%$ MOLM (4.43) while 7.5\% MOLM reflected worst value (4.65). All nutrient digestibilies, except CF and nutrient values (TDN, DCP and DE) of experimental diets were significantly decreased with increasing MOLM level in the diet. All carcass traits were not affected by dietary treatments. There were no significant differences among dietary treatments in most blood constituents (total protein, bilirubin, cholesterol, urea-N, creatinine, ALT and AST). Glucose, albumin, globulin and Alb/Glob ratio were significantly affected by MOLM inclusion in the diet. Glucose was increased $(\mathrm{p}<0.05)$ in rabbits fed MOLM diets compared to the control. Albumen and Alb/ Glo ratio were decreased ( $\mathrm{p}<0.05$ ). However, globulin was increased in rabbits fed $7.5 \%$ MOLM compared to those fed MOLM-free diet or $15 \%$ MOLM. All blood biochemical parameters were within the normal range for healthy rabbits. IgM and Anti-nuclear Antibody (ANA) were increased ( $\mathrm{p}<0.05$ ) in MOLM diets compared with the control. Economic efficiency (E. E) and relative E. E (\%) were increased by increasing MOLM level in the diets. It could be concluded that Moringa oleifera leaves meal can be used as a substitute of soybean meal as a source of protein in rabbit's diets without detrimental effects on productive performance, health status and economic efficiency.

Keywords: Rabbits, Moringa oleifera leave meal, productive performance, digestibility, carcass traits, blood parameters and economic efficiency.

\section{INTRODUCTION}

In Egypt, there is a large gab in animal protein between the demand and that available for human consumption. Moreover, the gab is increasing because the population is increasing more rapidly than the increase in production. However, gab could be decreased by rabbit farming (FAO, 1987). Rabbits are characterized by short generation interval, high reproductive rate and prolificacy, high feed efficiency and simple housing requirements (Daader et al., 1999). In addition, rabbits have a high ability to feed on diets containing forages and fibrous by-products (Cheeke, 1986, Aboul-Ela et al., 2011 and Bakr et al., 2019).

Soybean meal is considered the main protein source in rabbit's diet. The price of soybean meal has been increasing continuously in recent years, especially after the discovery of mad cow disease in the last decade. Therefore, search for cheaper new plant protein source is urgent (Zeweil et al., 2008).

Moringa oleifera leaves meal can be used to replace soybean meal in rabbit's diet up to $15 \%$ without any adverse effect on growth performance, hematology and blood biochemistry (Odetala et al., 2012). M.oleifera leaves meal has a high protein content ranging from 20 to $33 \%$ on dry matter basis, Moreover, the protein is of a high quality. It has significant quantities of all the essential and non-essential amino 
acids. Therefore, MOLM contains considerable levels of lysine and methionine (Foidl and Paull, 2008 and Abdel-Azeem et al., 2017). M. Oleifera leaves meal also has considerable quantities of macro and microelements, especially iron and selenium and is considered to be an excellent source of many vitamins (A, B, C and E) and bio-active components (Abdel-Azeem et al 2017). M. Oleifera leaves and fruits prevent morphological changes and oxidative damage in human and animals by enhancing the activities of antioxidant enzymes, reducing generation of free radicals (Sreelather and Padma, 2009 and Osman et al., 2012). The presence of antioxidants in moringa leaves promotes the immune system of animals against infection (Yang et al., 2006 and Jaiswall et al., 2009). Bauotene et al. (2011) reported that supplementation of $\mathrm{M}$. Oleifera leaf meal at $3 \%$ improved survival rate in growing rabbits.

The objective of the present study was to investigate the effect of varying levels of Moringa oleifera leaves meal as a substitute of soybean meal in rabbit's diets on growth performance and immunity of growing rabbits under North Sinai conditions.

\section{MATERIALS AND METHODS}

The present study was conducted in the rabbitry farm of the Department of Animal and Poultry Production, Faculty of Environmental Agriculture Sciences, Arish University, North Sinai, Egypt. The study lasted for 8 weeks starting January $1^{\text {st }}$ till the end of February 2018.

\section{Preparation of Moringa oleifera leaves meal (MOLM):}

Moringa oleifera leaves (MOLM) were harvested at the age of 2 months in a private farm at Kafr Saqr District, Sharqia governorate, Egypt. The leaves were air dried under shade until their moisture content reached almost $10 \%$. They were turned several times in order to retain their greenish coloration (about 72 hour). The dry leaves were then milled, sieved (1 mm mesh) and stored in a well tight polyethylene bags at room temperature until they were used. Samples of dry Moringa oleifera leaves meal (MOLM) were taken for chemical analysis. MOLM was analyzed for crude protein (CP), crude fiber (CF), ether extract (EE), ash, calcium (Ca) and phosphorus (P) according to A. O. A. C (2012).

\section{Animals and the experimental design:}

Thirty six newly weaned New Zealand White (NZW) unsexed (6 week's old and 858 g averge body weight) were randomly allocated into three dietary treatment groups, each of 12 animals. Each group was sub-divided into four replicates with three animals each. The 1st treatment group (control, T0) was fed a pelleted control diet, the 2nd treatment group ( $\mathrm{T}$ 7.5) and the 3rd treatment group (T 15) were fed diets containing 7.5 and 15\% MOLM substituting 50 and 100\% soybean meal, respectively (Table 1). MOLM was handily mixed with feed ingredients and the experimental diets were pelleted under a temperature of $70 \mathrm{oC}$ and $0.3 \mathrm{~cm}$ diameter and $2 \mathrm{~cm}$ length. The experimental diets were formulated to meet the nutrients requirements of growing rabbits according to NRC (1994). The composition of the experimental diets is showed in Table (1). Rabbits were housed as three in galvanized wire cage (3/cage) measured $(40 * 40 * 30$ $\mathrm{cm}$ ) in a well-ventilated building (natural air and light throw the window). Cages were provided with feeders and automatic nipple drinkers. The experimental diets and fresh water were supplied ad-libitum twice daily at 8.00 AM and 6.00 PM. All rabbits were kept under the same managerial, hygienic and environmental conditions. Individual body weight and feed intake were recorded weekly. Body weight gain and feed conversion ratio ( $\mathrm{g}$ feed/ $\mathrm{g}$ gain) were estimated.

\section{Digestibility trials:}

At the end of the experimental period (14 wk of age), digestibility trials were carried out to estimate the nutrient's digestibility and feeding values of the experimental diets. Three male rabbits were chosen randomly from each group and housed individually in metabolism cages that allow for collection of feces. The same feeding regime used during the feeding trial was also used during the digestibility trial. A preliminary period of 10 days was followed by 7 days as a collection period for feces. Feed intake was recorded daily and the feces of each rabbit was collected daily in the morning. Any shaded hair or foreign materials were discarded. The feces were sprayed with $2 \%$ boric acid for trapping any ammonia released, then was dried at $60 \mathrm{oC}$ for 36 hours. At the end of the collection period, all dried feces for each rabbit was mixed, grounded and stored until chemical analysis. Diets and feces were analyzed according to A. O. A. C (2012). The nutritive values of the experimental diets were estimated as digestible crude protein (DCP \%), total digestible nutrients (TDN) and digestible energy (DE, Kcal/kg diet). Values of total digestible nutrients (TDN) were calculated according to the equation described by Cheeke et al. (1982) as follows: 


$$
\mathrm{TDN} \%=\% \mathrm{DCP}+\% \mathrm{DCF}+\% \mathrm{DNFE}+2.25(\% \mathrm{DEE})
$$

Digestible energy (DE, Kcal/kg diet) was calculated according to the formula described by Schiemann et al. (1972), cited by El- Kerdawy (1997) as follows:

$\mathrm{DE}(\mathrm{Kcal} / \mathrm{kg}$ diet $)=5.28(\% \mathrm{DCP}, \mathrm{g} / \mathrm{kg})+9.51(\% \mathrm{DEE}, \mathrm{g} / \mathrm{kg})+4.2(\% \mathrm{DCF}+\% \mathrm{DNFE} \mathrm{g} / \mathrm{kg}) \pm 0.3$

Table (1): Formulation (\%) of the experimental diets.

\begin{tabular}{|c|c|c|c|}
\hline \multirow{2}{*}{ Item } & \multicolumn{3}{|c|}{ The experimental diet ${ }^{1}$} \\
\hline & T0 & $\mathrm{T} 7.5$ & $\mathrm{~T} 15$ \\
\hline Alfalfa hay $(15 \%)$ & 29 & 29 & 29 \\
\hline Soybean meal $(44 \%)$ & 15 & 7.5 & - \\
\hline Moringa oleifera leaves meal (MOLM) & - & 7.5 & 15 \\
\hline Barley grains & 15 & 15 & 15 \\
\hline Yellow corn & 10 & 10 & 10 \\
\hline Wheat bran & 26 & 26 & 26 \\
\hline Molasses & 3 & 3 & 3 \\
\hline Salt & 0.3 & 0.3 & 0.3 \\
\hline Limestone & 0.9 & 0.9 & 0.9 \\
\hline Vitamins and mineral mixture2 & 0.3 & 0.3 & 0.3 \\
\hline DL-Methionine & 0.1 & 0.1 & 0.1 \\
\hline Di-Calcium phosphate & 0.4 & 0.4 & 0.4 \\
\hline Total & 100 & 100 & 100 \\
\hline \multicolumn{4}{|c|}{$\begin{array}{l}{ }^{1} \text { Experimental diets; TO = control diet, containing no MOLM; T } 7.5=\text { diet containing } 7.5 \% \text { MOLM; T15 = diet } \\
\text { containing } 15 \% \text { MOLM. } \\
\text { - Each } 3 \mathrm{~kg} \text { of premix contains: Vit. A } 6000000 \mathrm{iu} \text {, Vit. D3 } 900000 \mathrm{iu} \text {, Vit. E } 40000 \mathrm{mg} \text {, VIt } \mathrm{k3} 2000 \mathrm{mg} \text {, Vit. B1 } 2000 \\
\text { mg, Vit. B2 } 4000 \mathrm{mg} \text {, Vit. B6 } 2000 \mathrm{mg} \text {,Vit.B12 } 10 \mathrm{mg} \text {,Biotin } 50 \mathrm{mg} \text {, Pantothenic acid } 10000 \mathrm{mg} \text {, Nicotinic acid } 50000 \\
\text { mg, Folic acid } 3000 \mathrm{mg} \text {, Choline chloride } 250000 \mathrm{mg}, \mathrm{Mg} 8500 \mathrm{mg} \text {, Zinc } 50000 \mathrm{mg} \text {, Iron } 50000 \mathrm{mg} \text {, Copper } 5000 \mathrm{mg} \text {, } \\
\text { Iodine } 200 \mathrm{mg} \text {, Selenium } 100 \mathrm{mg} \text { and Cobalt } 100 \mathrm{mg} \text {. }\end{array}$} \\
\hline
\end{tabular}

\section{Blood sampling:}

At slaughter, individual blood samples were collected in dry clean non-heparinized tubes (from the same slaughtered rabbits) and allowed to clot at room temperature and then centrifuged at $3000 \mathrm{rpm}$ for 15 minutes and the serum was separated and stored at $-20 \mathrm{oC}$ until analysis. Serum total protein and glucose were calorimetrically determined using Kits supplied by Bio Merieux, France. Urea and creatinine calorimetrically determined using Kits supplied by Diamond, Egypt. Albumin, bilirubin, ALT and AST were calorimetrically determined using Kits supplied by Randox, England. Serum globulin was obtained by difference (Total protein minus albumin). Cholesterol was calorimetrically determined using Kits supplied by Spectrum, Egypt. Serum immunoglobulin profile (igG, igA and igM) and Anti-nuclear Antibody (ANA) were determined using ELISA technique.

\section{Economic efficiency:}

Economic efficiency was calculated as the ratio between incomes price of weight gain and the cost of feed consumed over 6-14 weeks of age.

\section{Statistical analyses:}

Data were subjected to statistical analysis by the SAS (2004) computer program using the general linear models (GLM). Significances among treatment means were tested using Duncan's multiple range test (Duncan, 1955).

\section{RESULTS AND DISCUSSION}

\section{Chemical Analysis of MOLM and Experimental diets:}

Table (2) showed that the proximate chemical composition of MOLM was within the range values reported by pervious researchers (Ghada, 2015; Ahmed, 2017 and Omara et al., 2017). The CF, NFE and ash values were nearly similar for the experimental diets. The CP content was decreased while EE content 
was increased with increasing MOLM inclusion in the experimental diets (Table 2). This is due to the fact that CP content of MOLM (29.49\%) is lower than that of soybean meal (44\%) which is used as a source of protein in rabbit's diet. However, EE content of MOLM (7.24\%) is higher than that of soybean meal (2.08), indicating that MOLM is a source of fats.

\section{Growth performance :}

No significant differences were observed among the three dietary treatments in live body weight (LBW) and daily weight gain (DWG) of growing rabbits during the experimental period (Table 3). Mean values of live body weight and daily weight gain were decreased slightly with increasing MOLM level in rabbit's diets. This may be due to low DCP\% of MOLM diets (12.54 and 10.56\%) for T 7.5 and T15 compared to $13.80 \%$ of the diet without MOLM (T 0). This result is in accordance with that of Odetola $e t$ al. (2012) who found that MOLM can be used to replace soybean meal up to $15 \%$ substitute level in the rabbit's diet without adverse effect on the growth performance. These results can be explained as MOLM has better protein quality, possibly resulting from a higher methionine and lysine contents. Also, MOLM is rich in vitamin A which is important in rabbit growth. Pond et al., (1995) reported that deficiency of vitamin $\mathrm{A}$ in rabbit's diet led to poor growth.

Total feed intake $(\mathrm{kg} / \mathrm{head})$ and feed conversion ratio are presented in Table (4). Total feed intake wasn't significantly ( $p>0.05)$ influenced by replacing MOLM with soybean meal in the rabbit's diets. However, the feed conversion ratio was significantly affected by the dietary treatments. The diet without MOLM (T 0) had the best value (4.28) and the diet with 7.5\% MOLM inclusion (T 7.5) had the lowest value (4.65).

\section{Nutrients digestibility and nutritive values of experimental diets:}

Table (5) showed that all nutrients digestibility coefficients (except CF digestibility of 15\% MOLM substitution) were significantly lower $(\mathrm{p}<0.05)$ than those of MOLM-free diet (control, T0). Meanwhile, no significant differences were found in all nutrients digestibility coefficients, except EE digestibility between the diet without MOLM (T 0) and 7.5\% MOLM substitution. These results are in line with those obtained by Sun et al. (2018) who found that DM, CP and energy digestibility decreased when MOLM substitute levels were increased. This may be due to the presence of tannins in MOLM which have the ability to form complexes with macromolecules such as proteins and polysaccharides (De-Bruyne et al., 1999 and Dei et al., 2007). However, Ogbe and Affiku (2011) found that MOLM contains $21.19 \%$ tannins.

As shown in Table (5), there are significant differences $(\mathrm{p}<0.01)$ in DCP\% among the experimental diets. However, the control diet ( $\mathrm{T} 0$ ) had the highest value (13.80\%) versus 12.54 and $10.56 \%$ for MOLM diets (T 7.5 and T 15), respectively. Similarly, Vidjannagni et al. (2018) found that DCP \%of MOLM diets significantly decreased when MOLM substitute levels were increased in rabbit's diets. TDN \% and DE $(\mathrm{kcal} / \mathrm{kg})$ of MOLM diet $(\mathrm{T} 15)$ were significantly $(\mathrm{p}<0.05)$ lower than those of the control diet (T 0), while no significant differences in TDN and DE ( $\mathrm{kcal} / \mathrm{kg}$ ) were found between the control diet and MOLM diet (T 7.5). In the same trend, Sun et al. (2018) reported that the apparent digestible energy of the diet without MOLM was significantly higher $(p<0.05)$ than those of $30 \%$ MOLM substitution.

Table (2): Proximate composition of MOLM and experimental diets.

\begin{tabular}{lcccc}
\hline \multirow{2}{*}{ Item } & MOLM1 & \multicolumn{3}{c}{ Experimental diets2 } \\
\cline { 3 - 5 } & & $\mathrm{T} 0$ & $\mathrm{~T} 7.5$ & $\mathrm{~T} 15$ \\
\hline DM\% & 89 & 90.6 & 90.6 & 90.7 \\
Composition of DM\% & & & \\
OM & 90.34 & 91.39 & 91.15 & 90.90 \\
$\mathrm{CP}$ & 29.49 & 17.77 & 16.41 & 15.21 \\
$\mathrm{CF}$ & 10.01 & 13.60 & 13.73 & 13.86 \\
$\mathrm{EE}$ & 7.24 & 3.32 & 3.69 & 4.02 \\
NFE & 43.60 & 56.7 & 57.32 & 57.81 \\
Ash & 9.66 & 8.61 & 8.85 & 9.10 \\
\hline 1MOLM, Moringa oleifera leaves meals 2Experimental diets, T0 TO Control, containing no MOLM; \\
T7.5 = Containing 7.5\% MOLM; T15= Containing $15 \%$ MOLM
\end{tabular}


Table (3): Live body weight and daily gain of growing rabbits as influenced by dietary treatment.

\begin{tabular}{lcccc}
\hline \multirow{2}{*}{ Item } & \multicolumn{3}{c}{ Treatment1,2 } & S.E.3 \\
\cline { 2 - 5 } & T0 & T7.5 & T15 \\
\hline Live body weight $(\mathrm{g})$ & & & & \\
6 wk. & 859 & 859 & 814 & 26 \\
10 wk. & 1606 & 1627 & 1517 & 62 \\
14 wk. & 2269 & 2162 & 2149 & 77 \\
Daily weight gain (g) & & & \\
6-10 wk. & 26.6 & 27.4 & 25.1 & 1.5 \\
10-14 wk. & $23.7^{\mathrm{a}}$ & $19.1^{\mathrm{b}}$ & $22.6^{\mathrm{a}}$ & 0.83 \\
6-14 wk. & 25.2 & 23.3 & 23.8 & 1.03 \\
\hline
\end{tabular}

1 Values are least-squares means. 2 Treatments, $T 0=$ Control, containing no MOLM;

T7.5 = Containing 7.5\% MOLM; T15= Containing 15\% MOLM.

S.E. 3 = Largest standard error of the means.

$a, b$ Means in the same row with different superscripts differ $(P<0.05)$.

Table (4). Feed intake and feed conversion ratio as influenced by dietary treatments

\begin{tabular}{lllll}
\hline Item & \multicolumn{2}{l}{ Treatment1,2 } & \multirow{2}{*}{ S.E.3 } \\
\cline { 2 - 4 } & T0 & T7.5 & T15 & \\
\hline Total feed intake (kg/head) & & & & 0.013 \\
6-10 wk. & $2.55^{\mathrm{a}}$ & $2.70^{\mathrm{b}}$ & $2.54^{\mathrm{a}}$ & 0.024 \\
10-14 wk. & $3.49^{\mathrm{a}}$ & $3.35^{\mathrm{b}}$ & $3.55^{\mathrm{a}}$ & 0.035 \\
6-14 wk. & 6.05 & 6.05 & 6.10 & \\
Feed conversion ratio & & & & 0.077 \\
6-10 wk. & 3.41 & 3.52 & 3.53 & 0.070 \\
10-14 wk. & $5.28^{\mathrm{a}}$ & $6.26^{\mathrm{b}}$ & $5.43^{\mathrm{a}}$ & 0.056 \\
6-14 wk. & $4.28^{\mathrm{a}}$ & $4.65^{\mathrm{b}}$ & $4.43^{\mathrm{a}}$ & \\
\hline
\end{tabular}

1 Values are least-squares means. 2 Treatments, T0 = Control, containing no MOLM;

T7.5 = Containing 7.5\% MOLM; T15= Containing 15\% MOLM.

S.E.3 = Largest standard error of the means.

$a, b$ Means in the same row with different superscripts differ $(P<0.05)$.

Table (5): Effect of dietary inclusion of varying levels of MOLM on apparent nutrients digestion coefficients and nutritive values of the experimental diets

\begin{tabular}{|c|c|c|c|c|c|}
\hline \multirow{2}{*}{ Parameter } & \multicolumn{3}{|c|}{ Treatment1 } & \multirow{2}{*}{ S. E2 } & \multirow{2}{*}{ Sig 3} \\
\hline & T 0 & $\mathrm{~T} 7.5$ & $\mathrm{~T} 15$ & & \\
\hline \multicolumn{6}{|c|}{ Digestibility coefficient (\%) } \\
\hline $\mathrm{DM}$ & $69.48^{\mathrm{a}}$ & $69.10^{\mathrm{a}}$ & $63.70^{\mathrm{b}}$ & 1.64 & $*$ \\
\hline $\mathrm{OM}$ & $71.51^{\mathrm{a}}$ & $70.81^{\mathrm{ab}}$ & $66.17^{\mathrm{b}}$ & 1.64 & $*$ \\
\hline $\mathrm{CP}$ & $77.69^{\mathrm{a}}$ & $76.41^{\mathrm{a}}$ & $69.44^{\mathrm{b}}$ & 1.73 & $* *$ \\
\hline $\mathrm{EE}$ & $87.87^{\mathrm{a}}$ & $81.77^{\mathrm{b}}$ & $74.90^{c}$ & 1.57 & $* *$ \\
\hline $\mathrm{CF}$ & 27.23 & 32.18 & 26.50 & 2.78 & \\
\hline NFE & $79.22^{\mathrm{a}}$ & $77.76^{\mathrm{ab}}$ & $74.23^{\mathrm{b}}$ & 1.55 & $*$ \\
\hline \multicolumn{6}{|c|}{ Nutritive values (\%) } \\
\hline TDN & $68.99^{\mathrm{a}}$ & $68.30^{\mathrm{ab}}$ & $63.91^{\mathrm{b}}$ & 1.56 & $*$ \\
\hline DCP & $13.80^{\mathrm{a}}$ & $12.54^{\mathrm{b}}$ & $10.56^{c}$ & 0.29 & $* *$ \\
\hline $\mathrm{DE}(\mathrm{kcal} / \mathrm{kg})$ & $3048.47^{\mathrm{a}}$ & $3006.56^{\mathrm{a}}$ & $2800.73^{\mathrm{b}}$ & 68.03 & $*$ \\
\hline
\end{tabular}

Treatments, $\mathrm{TO}=$ Control, containing no MOLM;

T7.5 = Containing 7.5\% MOLM; T15= Containing 15\% MOLM.

S. E2 = Largest standard error of the means.

Sig3 = significance level.

$a, b$ and $c$ Means in the same row with different superscripts differ.

*Significance at $p<0.05$

** Significance at $p<0.01$ 


\section{Carcass traits:}

Data in Table (6) showed no significant differences among dietary treatments in all carcass traits and internal organs. Liver, kidneys and heart appeared normal in size and did not show any signs of toxicity. These results are in agreement with those obtained by Dougnen et al, (2012) and Ahmed (2017).

Table (6). Effect of dietary treatments on carcass characteristics of rabbits.

\begin{tabular}{lllll}
\hline Item & Treatment1,2 & & T15 & \\
\cline { 2 - 4 } & T0 & T7.5 3 & 60 \\
\hline Pre-slaughter wt. (g) & 2143 & 2193 & 2247 & 40 \\
Empty carcass wt. (g) & 1273 & 1337 & 1329 & 41 \\
Total edible parts4 (g) & 1350 & 1419 & 1412 & 6.12 \\
Goblets wt.5 (g) & 77.8 & 82.2 & 83.8 & 4.2 \\
Head (g) & 116.0 & 127.2 & 119.4 & 5.6 \\
Liver (g) & 59.2 & 62.4 & 64.4 & 0.54 \\
Kidneys (g) & 12.4 & 13.4 & 13.6 & 0.42 \\
Heart (g) & 6.2 & 6.4 & 5.8 & 0.64 \\
Dressing \% & 63.07 & 64.76 & 62.85 & \\
\hline
\end{tabular}

1 Values are least-squares means. Treatments, T0 = Control, containing no MOLM;

T7.5 = Containing 7.5\% MOLM; T15= Containing 15\% MOLM.

S. E3 = Largest standard error of the means.

4Total edible parts weight $=$ Empty carcass wt. $($ with head $)+$ Goblets wt.

5 Goblets $w t .=$ Liver $w t .+$ Kidneys $w t .+$ Heart $w t$.

\section{Blood constituents:}

As shown in Table (7), glucose was increased significantly $(\mathrm{p}<0.05)$ in MOLM diets (T 7.5 and T15) compared with that of MOLM-free diet (T 0). This may be due to MOLM having various phytochemical and bioactive components such as the trace metal ions, vitamins, alkaloids, carotenoids and polyphenols which enhance rabbit's health in the long term (Sravanthi and Rao, 2014). Albumin, globulin and Alb/Glo

Table (7). Serum biochemical parameters of rabbits as influenced by dietary treatments

\begin{tabular}{lllll}
\hline \multirow{2}{*}{ Biochemical parameter } & \multicolumn{3}{l}{ Treatment1,2 } & S.E.3 \\
\cline { 2 - 5 } & T0 & T7.5 & T15 & 5.00 \\
\hline Glucose $(\mathrm{mg} / \mathrm{dl})$ & $121^{\mathrm{a}}$ & $132^{\mathrm{b}}$ & $132^{\mathrm{b}}$ & 0.14 \\
Total protein (g/dl) & 6.17 & 6.17 & 6.03 & 0.18 \\
Albumin (g/dl) & $4.00^{\mathrm{a}}$ & $3.57^{\mathrm{b}}$ & $3.96^{\mathrm{a}}$ & 0.17 \\
Globulin (g/dl) & $2.17^{\mathrm{a}}$ & $2.60^{\mathrm{b}}$ & $2.07^{\mathrm{a}}$ & 0.21 \\
Alb/Glo ratio & $1.85^{\mathrm{a}}$ & $1.39^{\mathrm{b}}$ & $1.97^{\mathrm{a}}$ & 0.008 \\
Bilirubin (mg/dl) & 0.033 & 0.043 & 0.04 & 7.92 \\
Cholesterol (mg/dl) & 60.67 & 58.00 & 45.67 & 3.36 \\
Urea nitrogen (mg/dl) & 45.66 & 41.00 & 42.66 & 0.049 \\
Creatinine (mg/dl) & 0.913 & 0.883 & 0.923 & 7.37 \\
ALT (U/L) & 54.66 & 58.66 & 48.33 & 2.49 \\
AST (U/L) & 39.66 & 38.33 & 34.66 & \\
\hline
\end{tabular}

1 Values are least-squares means. 2Treatments, TO = Control, containing no MOLM;

T7.5 = Containing 7.5\% MOLM; T15= Containing 15\% MOLM.

$S . E 3=$ Largest standard error of the means.

$a$ and $b$ Means in the same row with different superscripts differ $(P<0.05)$.

were significantly $(\mathrm{p}<0.05)$ influenced by MOLM inclusion in the rabbit's diets. Albumin and Alb/Glo levels were lower. Meanwhile globulin was increased $(\mathrm{p}<0.05)$ with rabbits fed 7.5\% MOLM diet compared with those fed the control or 15\% MOLM diet. However, total protein, bilirubin, cholesterol, urea-N, creatinine, ALT and AST weren't significantly influenced by the dietary treatments. These results are in line with those reported by Ahemen et al. (2013). Cholesterol level deceased ( $>0.05)$ with increasing MOLM inclusion in the diets. This may be due to the hypolipidemic effect of bioactive phytoconstituents such as alkaloids and saponins (Dong et al., 2007). Ghasi et al. (2000) showed that the 
mechanism of cholesterol reduction is due to lowering plasma concentrations of LDL by $\beta$-sitosterol, the bioactive phytoconstituent isolated from MOLM.

Serum biochemical parameters, except urea-N, in this study were within the normal range of healthy rabbits (Manning et al., 1994). This explained that nutrients and dietary protein of MOLM were adequate and well utilized by rabbits. So, MOLM can be used up to $15 \%$ as replacement for soybean meal in rabbit's diets without any adverse effect on growth performance of growing rabbits.

\section{Immune response:}

Results in Table (8) showed that IgG and $\operatorname{IgA}$ were not significantly affected by dietary treatments. Meanwhile, IgM was significantly affected by dietary treatments. However, IgM was significantly increased in rabbits fed MOLM diets compared with those fed the control diet. Anti-nuclear Antibody (ANA) was significantly increased by increasing MOLM inclusion in the diet. The ANA of rabbits fed $15 \%$ MOLM was higher $(\mathrm{p}<0.05)$ than those fed $7.5 \%$ MOLM or the control diet. These results are in agreement with those of Badawi et al. (2017) and El-Gindy et al. (2017). This is could be due to the presence of considerable levels of antioxidants (Vit $\mathrm{E}$ and $\mathrm{C}$, carotenoids and selenium) in MOLM (Klasing and Leshchincky, 2000 and Gallois et al., 2005).

\section{Economic efficiency:}

Total feed cost decreased with increasing MOLM substitute level in the rabbit's diets (Table 9). The low feeding cost of MOLM diets is due to the low price of MOLM which equals $4.2 \mathrm{LE} / \mathrm{kg}$ compared to $7.17 \mathrm{LE} / \mathrm{kg}$ soybean meals. In the time, total feed intake and total weight gain were nearly similar in the different dietary treatments. These results revealed that net revenue /rabbits (L.E), economic efficiency (E.E) and relative E.E (\%) were higher in the 15\% MOLM diet compared to control or 7.5\% MOLM diets. These results are in agreement with those obtained by Abd-Allah (2017).

Table (8): Immune responses of rabbits as influenced by dietary treatments.

\begin{tabular}{|c|c|c|c|c|}
\hline \multirow{2}{*}{ Constituent } & \multicolumn{3}{|c|}{ Treatment 1,2} & \multirow{2}{*}{ S. E3 } \\
\hline & T 0 & T 7.5 & T 15 & \\
\hline $\operatorname{IgG}(\mathrm{mg} / \mathrm{dl})$ & 380 & 365.66 & 302.33 & 0.001 \\
\hline $\operatorname{IgA}(\mathrm{mg} / \mathrm{dl})$ & 0.10 & 0.067 & 0.100 & 0.013 \\
\hline $\operatorname{IgM}(\mathrm{mg} / \mathrm{dl})$ & $18.36^{\mathrm{a}}$ & $24.70^{\mathrm{b}}$ & $23.90^{\mathrm{b}}$ & 2.52 \\
\hline ANA & $0.127^{\mathrm{a}}$ & $0.190^{\mathrm{a}}$ & $0.676^{\mathrm{b}}$ & 0.17 \\
\hline
\end{tabular}

Table (9): Economic efficiency as affected by Moringa oleifera leaves meal (MOLM) in rabbits' diet.

\begin{tabular}{lccc}
\hline \multirow{2}{*}{ Item } & \multicolumn{3}{c}{ Dietary Treatment* } \\
\cline { 2 - 4 } & T 0 & T 7.5 & T 15 \\
\hline Price/kg diet. (L.E) & 4.42 & 4.20 & 3.98 \\
Total feed intake/rabbit(g) & 6005 & 6005 & 6010 \\
Total feed cost/rabbit (L.E) & 26.54 & 25.22 & 23.92 \\
Total weight gain/rabbit(g) & 1410 & 1303 & 1335 \\
Feed cost/kg gain (L.E) & 18.82 & 19.35 & 17.92 \\
Price/kg weight gain (L.E) & 32 & 32 & 32 \\
Total revenue/weight gain(L.E) & 45.12 & 41.70 & 42.72 \\
Net revenue/rabbit (L.E) & 18.58 & 16.48 & 18.80 \\
Economic efficiency (E.E) & 70.00 & 65.34 & 78.59 \\
Relative E. E (\%) & 100 & 93.34 & 112.27 \\
\hline
\end{tabular}

*Treatments, $T 0=$ Control, containing no MOLM;

T7.5 = Containing 7.5\% MOLM; T15= Containing $15 \%$ MOLM. 


\section{CONCLUSION}

Moringa oleifera leaves meal can be used up to $15 \%$ in rabbit's diets as a protein source without any detrimental effects on productive performances, carcass traits and physiological status.

\section{REFERENCES}

Abd-Allah, M. S. M. (2017). Productive performance of rabbits fed Moringa oleifera M. Sc. Thesis, Fac. of Technology and Development, Zagazig University, Egypt.

Abdel-Azeem, A. F.; Mohamed, F. A.; EL-Shiekh, S. E. M. and Hessin, A. F. (2017). Maximizing productivity of Lohmann chickens by feeding diets inclusions different levels of Moringa oleifera leaf meal as a safe feed additive. J. Animal and poultry prod. Mansoura University, 8 (8): 319-328.

Aboul-ELa, S.S; Ali, F.A.F.; Madi, A. and Abdel-Naby, M.R.A. (2011). Olive cake meal as partial or complete substitute for clover hay in growing rabbit diets. Egyptian Journal of Nutrition and Feeds, $14 ; 109-119$.

Ahemen, T.; A. H. Abu and L. K. Iorgilim (2013). Physiological responses of rabbits fed graded levels of Moringa oleifera leaf meal (MOLM): Some aspects of hematology and serum biochemistry Archives of Applied Science Research, 5 (2): 172 - 176.

Ahmed, R. M. A. (2017). Evaluation of Moringa (Moringa oleifera) as a new feed for rabbits, M. Sc. Thesis, Department of Animal and Poultry production, Faculty of Technology and Development. Zagazig University.

A.O.A.C. (2012) Association of Official Analatical Chemists. Official methods of analysis. 19th Ed. A.O.A.C. Washington. DC, USA.

Badawi, Y. K; M. A. EL-Sawy and Nehad A. Ramadan (2017) Impact of dietary supplementation with moringa (Moringa oleifera) on productive performance, physiological response and immunity of growing rabbits. Egyptian Journal of Rabbit Science, 27 (2): 325-338.

Bakr, E. O. A.; M. M. Shetaewi and A. M. I. El-Desoky (2019). Effect of olive cake pulp as a partial or a complete substitute of wheat bran in growing rabbits' diet on growth performance, carcass traits and blood constituents under North Sinai conditions, J. Animal and Poultry Prod., Mansoura Univ., 10 (3): $83-88$.

Bouatene, D; L. G. Bohoua and S. Dabonne (2011). Effect of Moringa oleifera on growth performance and health status of young post-weaning rabbits. Research Journal of Poultry Sciences, 4 (1): 7-13.

Cheeke, P. R. (1986). Potentials of rabbit production in tropical and subtropical agricultural systems. J. Ani. Sci., 63:1581-1586.

Cheeke, P. R. (1987). Rabbit feeding and nutrition. Academic press. Ozlanda, Florida, U. S. A.

Cheeke, P. R.; N. M. Patton and G. S. Templeton (1982). Rabbit Production. 5th Ed. Print and Published. USA.

Daader, A. H; H. A. Gabr and T. S. T. Seleem (1999). Productive and reproductive performance of New Zealand white and Californian rabbit bucks as affected by supplementing vitamin "A" to the diet, during summer and winter seasons. 7th Science Conference on animal nutrition, 19-21 October., ElArish, North Sinai, Egypt, 551 - 564.

De-Bruyne, T; L. Pieters; H. Deelstra and A. Ulitink (1999). Condensed vegetable Tannins: biodiversity in structure and biological actives. In Biochemical systematic and Ecology, 27: 445 - 459.

Dei, H. K. ; S. P. Rose and A. M. Mackenzie (2007). Shea nut (vitellaria paradoxa) meal as a feed ingredient for poultry. In worlds poultry science Journal, 63 (4):611 - 624.

Dong, X. F.; W.W. Gao; J.M. Tong; H. Q. Jia; R. N. Sa and Q. Zhang (2007). Effect of palysavane (alfalfa extract) on abdominal fat deposition and Immunity in broiler chekens. Poult. Sci., 86: 19951959. 
Dougnon, T. J.; B. A. Aboh; T. M Kpodekon; S. Honvou and I. Youssao (2012). Effects of substitution of pellet of Moringa oleifera to commercial feed on rabbit's digestion, growth performance and carcass trait. Journal of Applied Pharmaceutical Science, 2 (9): 15-19.

Duncan D. B. (1955). Multiple rang and multiple F Test. Biometrics, 11, 1 - 42.

El-Gindy, Yassmin M.; H. S. Zeweil and M. Hamad (2017). Effects of Moringa oleifera leaf as a natural antioxidant on growth performance, blood lipid profiles and immune response of rabbits under moderate that stress. Egypt. Poult. Sci., Vol. (37) (11): 333-344.

El- Kerdawy, D. M. A. (1997). Olive pulp as a new energy source for growing rabbits. Egyptian journal of Rabbits Science, 7 (1): 1 - 12.

F. A. O. (1987). Rabbits production 12th session of the F. A. O. Regional Animal Production and Health commission for Asia and Pacific (APHCA) Held in Islamabad Pakistan from 5th to 10th October

Foidl, N. and R. Paull (2008). Moringa oleifera. In: the Encyclopedia of fruit and nutrient ABI, Oxford shine. UK Pp 509-512.

Gallois, M.; T. Gidenne; L. Forthun-Lamothe; I. Le Huerou-Luron and J. P. Lalles (2005). An early stimulation of solid feed intake slightly influences the morphological gut maturation in the rabbit. Reprod. Nutr. Dev., 45: 109 - 122.

Ghada S. EL-Esawy. (2015). Effect of supplementing different levels of Moringa oleifera plant leaves on productive performance of dairy Cows. Ph. D. thesis, Fac, of Agric, Kaferisheikh University.

Ghasi, S.; E. Nwobodo and J. O. Ofili (2000). Hypocholesterolemic effects of crude extract of leaf of Moringa oleifera Lam in high fat diet fed wistar rats. Journal of Ethnopharmacology, 69 (1): 21-25.

Jaiswall,D. P; A. Kumar; S. Mehta and G. Watal (2009). Effect of Moringa oleifera lam. Leaves aqueous extract therapy on hyperglycemic rats. J. Ethnopharmacal., 123 (3): 392 - 396.

Klasing, K. C. and T. V. Leshchincky (2000). Interactions between nutrition and immunity: Lesson from animal agriculture. In: Nutrition and immunology: principles and practices. M. E. Gersulin, S. B. German and C. L. Keen Eds. Humana press, Totowa, USA chap. 30, 363 - 374.

Manning, P. J.; D. H. Ringler and C. E. New comer (1994). The Biology of Laboratory Rabbit, 2nd ed. Academic press inc., San Diego, California, USA.

NRC (1994). Nutrient Requirements of Rabbits. National Academy of Science, Washington, DC. USA.

Odetola, O. M; O. O. Adetola; T. I. Ijadunola; O. Y. Adedeji and O. A. Adu (2012). Utilization of moringa (moringa oleifera) leaves meal as a replacement for soybean meal in rabbit's diets. Scholarly Journal of Agricultural Science, 12: 309 - 313.

Ogbe, A. O and J. P. Affiku (2011). Proximate study, Mineral and Anti-nutrient composition of Moringa oleifera leaves harvested from Lafia, Nigeria: potertial benefits in poultry nutrition and health. Journal of Microbiology, Biotechnology and Food Sciences, 1 (3): 296 - 308.

Omara, M. E.; Ghada S. EL-Esawy; W. A. Riad and A. M. A. Mohi EL-Din (2017). Effects of supplementing rabbits diets with Moringa oleifera dry leaves as different levels on their productive performance. Academia Journal of Biotechnology, 5 (1).

Osman, H. M.; M. E. Shayoub and E. M. Babiker (2012). The effect of Moringa oleifera leaves on blood parameters and body weights of Albino rats and rabbits. Jordan J. of Biological Sci., 5 (3): 147 - 150.

Pond, W. G; D. C. Chunch and K. R. Pond (1995). Basic animal nutrition and feeding 4th edition Johnwiley and Sons publication, New York USA. PP 495- 504.

SAS Institute Inc., (2004). SAS procedures Guide for personal computers, Statistical Analysis System Institute, Inc., Cary, N. C.

Schiemann, R.; K. Nehring; L. Hoffman; W. Jentsch and A. Chudy (1972). Energetische futterbewertung und energienormen. VEB Deutscher Landwirtschaftsveriag. Berlin. 344.

Sravanthi, J. and S. G. Rao (2014) Anti-oxidative studies in Moringa oleifera Lam. Annals of phytomedicine, 3 (2): $101-105$.

Srealather, S. and P. R. Padma (2009). Antiexidant activity and total phenolic content of Moringa oleifera leaves in two stages of maturity. J. Plant Food Human Nutri., 64: 303 - 311. 


\section{Baker}

Sun, B.; Y. Zhang; M. Ding; Q. Xi; G. Liu; X. Li; D. Liu and X. Chen (2018). Effects of Moringa oleifera leaves as a substitute for alfalfa meal an nutrient digestibility, growth performance, carcass trait, meat quality, antioxidant capacity and biochemical parameters of rabbits. Journal of Animal Physiology and Animal Nutrition, 102: 194 - 203.

Vidjannagni, S. D.; S. S. Toleba; H. Sina; D. Mahamadou; F. D. Daga; U. Natonnagnon; A. Adenile; A. Harouna; R. A. T. Aiha and L. Baba-Moussa (2018). Digestibility of Moringa oleifera Lam. Leaves meal based diet by Oryctolagus cuniculus. Journal of Animal Research and Nutrition, 3 2:1.

Yang, R. X; S. C. S. Tsou; T. C. Lee; L. C. Chang; G. Kuo and P. Y. Lai (2006). Moringa a novel plant nutrients. American Chemical Society Symposium series, 925: 224-239.

Zeweil, H. S.; M. H. Ahmed; M. M. EL-Adawy and B. Zaki (2008). Evaluation of Substituting Nigella seed meal as a source of protein for soybean meal in diets of New Zealand white rabbits. 9th World Rabbit Congress - June 10- 13, Verona - Italy.

\section{التقييم الغذائى لإحلال مسحوق أوراق المورينجا كمصدر بروتيني محل كسب فول الصويا فى علائق الأرانب

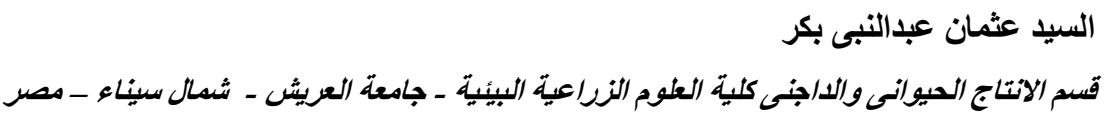

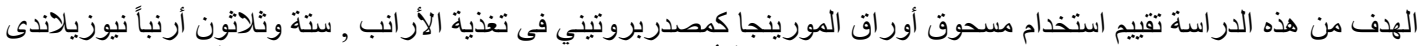

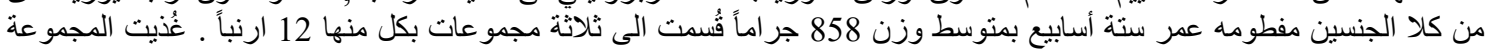

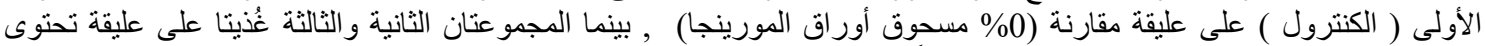

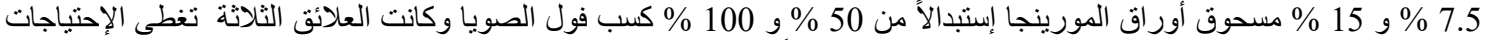

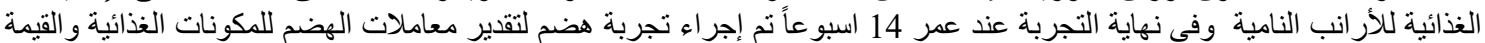

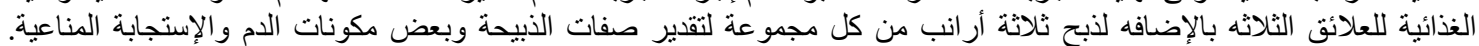

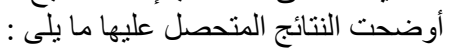

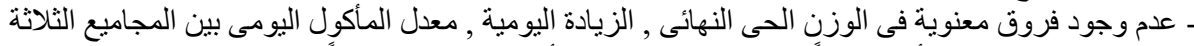

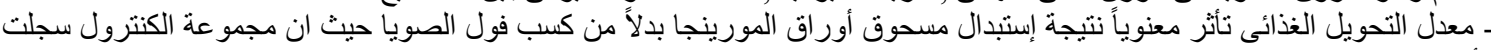

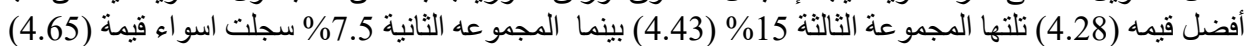

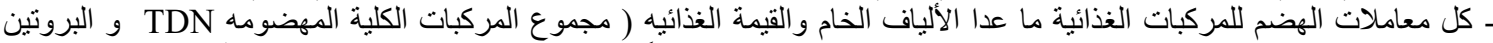

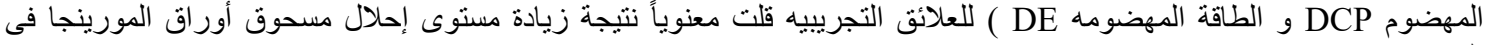
العلائق AST لم لم توجد اختلافات معنوية لمعظم مكونات الدم (البروتين الكلى , البيليروبين, الكوليسترول , اليوريا , الكرياتينيين , انزيمات الكبد

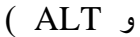

إزداد تركيز مستوى الجلوكوز معنوياً مع المجموعنان الثانية والثالثة والتى تغذت على علائق تحتوى على مسحوق أوراق المورينجا مقارنتاً بالمجمو عة الكنترول الزيز

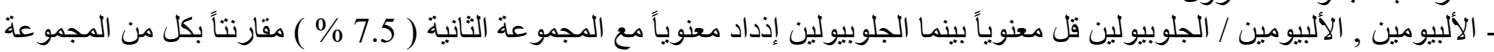

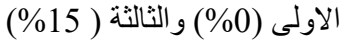

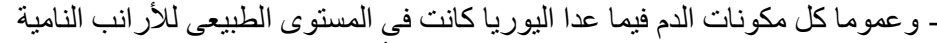

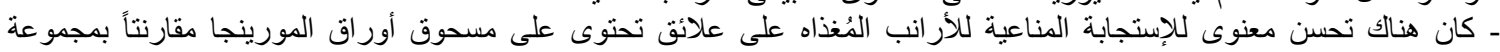
الكنترول ـ حققت المجمو عة الثالثة ( 15 \% \%) أعلى عائد اقتصادى مقارنتاً بمجمو عة الكنترول

الخلاصة: يمكن إدخال مسحوق أور اق المورينجا حتى مستوى 15 \% كمصدر بروتين بدلاً من كسب فول الصويا فى علائق الأرانب

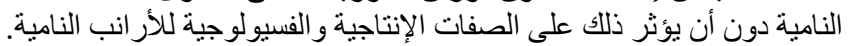

